\title{
SEISMIC VULNERABILITY ASSESSMENT OF A ROMANIAN HISTORICAL BUILDING UNDER NEAR-SOURCE EARTHQUAKE
}

\author{
N. CHIEFFO ${ }^{1 *}$, M. MOSOARCA ${ }^{1}$, A. FORMISANO ${ }^{2}$, P.B. LOURENÇO ${ }^{3}$ \\ ${ }^{1}$ Faculty of Architecture and Urbanism \\ Politehnica University of Timişoara \\ Traian Lalescu Street 2/A, 300223 Timişoara, Romania \\ email: nicola.chieffo@student.upt.ro (*corresponding author),marius.mosoarca@utp.ro \\ ${ }^{2}$ Department of Structures for Engineering and Architecture \\ School of Polytechnic and Basic Sciences, University of Naples "Federico II" \\ P.le V. Tecchio, 80125 Naples, Italy \\ e-mail: antoform@unina.it \\ ${ }^{3}$ Department of Civil Engineering \\ ISISE, Institute of Science and Innovation for Bio-Sustainability (IB-S), University of Minho \\ Azurém Campus, Guimaraes, Portugal \\ e-mail:pbl@civil.uminho.pt
}

Keywords: Vertical Ground Motion, Seismic Vulnerability Assessment, Non-Linear Dynamic Analysis, Damage Analysis

\begin{abstract}
The ground motion vertical component is generally ignored in the analysis of ordinary building structures, even though observed damages after last earthquakes highlighted its marked influence especially on the response of masonry structures. In the present research work, the effect of ground motion vertical components in case of near-source excitations has been analysed. The investigation has been made on the Banloc Castle, a historical masonry building damaged by the Banat-Voiteg earthquake occurred on December 1991 in the Region of Banloc in Romania. A FEM model of the building, setup with the DIANA FEA analysis software, has been investigated in the non-linear dynamic field. In particular, the records have been referred to the Banloc site, located $7.01 \mathrm{~km}$ far from the epicentre with a moment magnitude $M_{w}=5.5$ and a focal depth of $9 \mathrm{~km}$. The behaviour of the ground motion components has been characterised by the V/H peak ground acceleration ratio. In order to estimate the influence of the vertical seismic motion in terms of both displacements and stress regime, two different scenarios have been analysed. The first scenario has taken into account the horizontal component only, whereas the second one has analysed the simultaneous effects of three components of the seismic action. Finally, numerical damage patterns have been plotted aiming to simulate the real cracks detected in the case study after the considered seismic event.
\end{abstract}




\section{INTRODUCTION}

The existing unreinforced masonry (URM) buildings are typically identified as "potentially at risk" structures since, during an earthquake, they are not able to resist the simultaneous actions due to horizontal and vertical inertia forces. In general, the seismic design codes dealing with masonry structures take into account the effects of horizontal actions only, completely neglecting the vertical component of the design ground motion [1-5]. This circumstance is particularly relevant in case of near-field events, where the vertical actions are much more influential than the horizontal ones. In this framework, the studies proposed in [6] showed the relevance of the vertical component for seismic events, called near-field or near-source earthquakes, which are characterized by small site-source distances.

Generally, the vertical component of ground motion is mainly associated to the arrival of vertically propagating compressive P-waves and secondary shear S-waves. However, the propagation direction of volume waves $(\mathrm{P}$ and $\mathrm{S})$ is not influenced by the site geology, but by the site distance, the fault type and the magnitude. In these circumstances, it is evident that the effects induced by the ground motion vertical component are prominent in areas characterized by high hazard level. Therefore, they should be appropriately considered in the seismic behaviour analysis of existing masonry buildings.

Other studies $[7,8]$ have analyzed the behaviour of masonry buildings subjected to vertical seismic actions, asserting that the vertical component of the ground motion in epicentre areas characterized by a Joyner and Boore distance $\left(\mathrm{R}_{\mathrm{jb}}<30 \mathrm{~km}\right)$ causes a variation of the axial stress

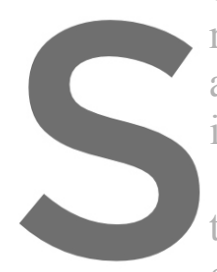
regime in the walls. Cons a reduction in terms of in terms of resistance, In this framework, the Castle of Banloc has of vertical accelerations on the seismic capacity of nsecutively, the dynamic amplification
the shear capacity of structural resistan
stability and ductility.
ocusing on the Banat-Voiteg seismic ev
been selected as a case study. In order
s on the seismic capacity of the examin due to soil stratigra
t element, which sh
to take into account th aphy leads to
how a deficit
the influence
near dynamic analysis have been carried out considering the ground motion records representative of the Register for free at https d wWH scipedia.comp to download the version without the watermark order to point out the influence of vertical component. Finally, the damages achieved from analytical modeliling have been presented, discussed and compared to the really detected ones.

\section{SEISMICITY OF THE BANAT REGION}

The Banat region is characterized by an important seismic activity observed in the years from 1991 to 2014. The main records have been obtained by the INCERC seismic network (Banloc Town-Hall and Timisoara stations) during the 1991 Banat earthquakes. In particular, the accelerometer records taken by INCERC for the cities of Timişoara and Banloc provided earthquakes with the following characteristics: (i) relatively short duration of 9-24 s and (ii) significant spectral values in the range 0.1-0.3 s, which extends up to $0.7 \mathrm{~s}$ for the Timişoara record and up to $1.2 \mathrm{~s}$ for the Banloc one.

Focusing on the event recorded in the city of Banloc, it is characterized by a reduced sitesource distance $(7.01 \mathrm{~km}$ far from the epicentre), which makes it as a near-source event. This event has showed an impulsive and high vertical peak acceleration of $1.2863 \mathrm{~ms}^{-2}$, a focal depth of $9 \mathrm{~km}$, a moment magnitude, $\mathrm{M}_{\mathrm{w}}$, of 5.5 and an intensity, I, of VIII according to Mercalli 
Intensity Scale (MCS).

The data provided by the SM-ROM-GL Earthquakes DB [9] related to the 1991 event occurred in the Banat Region are shown in Table 1

Table 1: Reference event occurred in the Banat seismogenic zone in December 1991.

\begin{tabular}{ccccccc}
\hline Earthquake & Date & LatN & LongE & Depth $-\boldsymbol{h}(\mathbf{k m})$ & $\mathbf{M}_{\mathbf{w}}$ & Station \\
\hline Banat-Voiteg & $1991 / 12 / 02$ & 45.45 & 21.12 & 9 & 5.5 & BNL1 \\
\hline
\end{tabular}

Furthermore, the ShakeMap of the event occurred and the geolocation of the city of Banloc are shown in Figure 1.

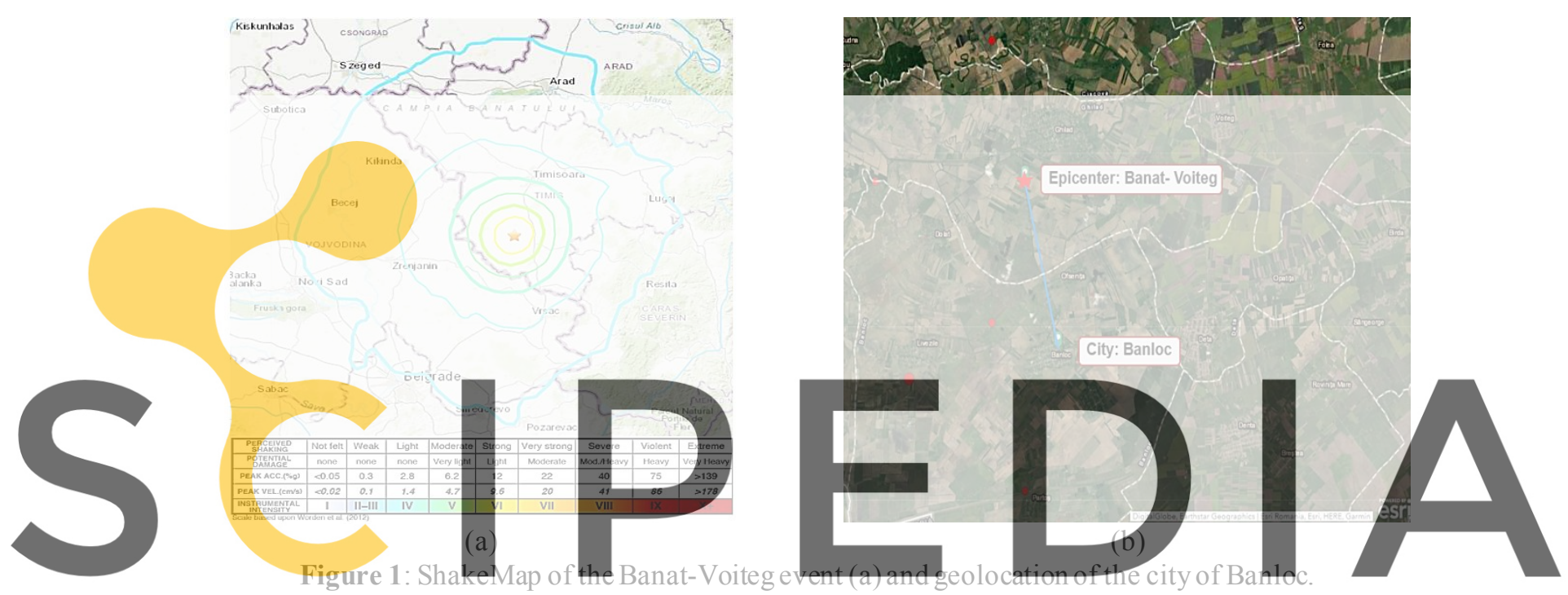

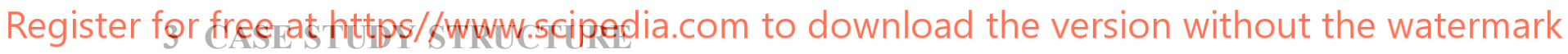

\subsection{History of the Bantoc Castle}

The Banat Region was released in 1716, when it was under Turkish rule, by the MarshalAustrian-Prince Eugene of Savoy Feld and was incorporated into the Habsburg Empire as a military province. Turkish domination destroyed the last vestiges of Western civilization and Austrian rulers had no concerns other than military ones. This is why Banat is poor in historic buildings, both in villages and in cities. In 1759 the construction of the castle of Banloc was completed.

The Castle of Banloc (Figure 2) is the most important monument of the municipality. It is a massive building with a "U" plan built in the early nineteenth century. The main façade faces south, while on the opposite side the two wings border a terraced courtyard. The castle is a massive historical masonry building with very heavy perimeter brick walls, having generally thickness of $0.90 \mathrm{~m}$, while the internal walls, made of the same material, have thickness of 0.80 m.

On the top, vaulted ceilings with thickness of $0.25 \mathrm{~m}$ are present. The inter-storey heights of first and second floors are $4.00 \mathrm{~m}$ and $5.70 \mathrm{~m}$, respectively. The roof is solid and robust, with 
a timber supporting structure, whose construction technique was frequently used in the Banat region.

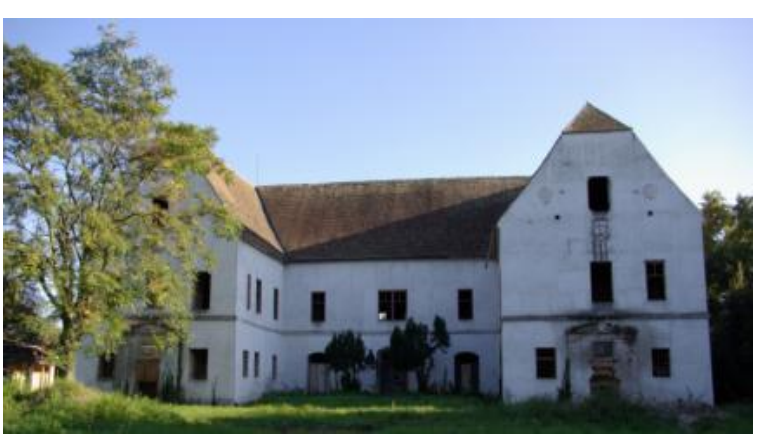

(a)

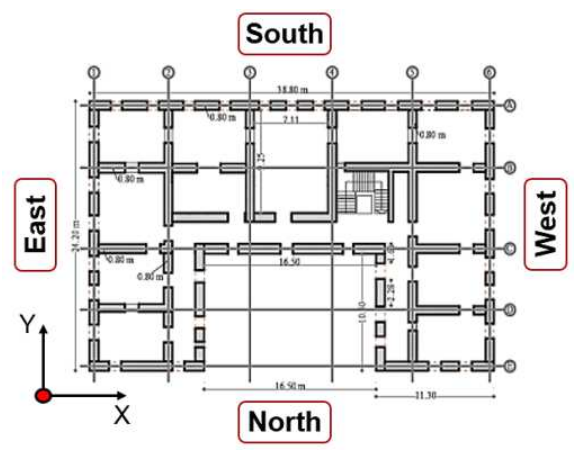

(b)

Figure 2: Castle of Banloc: (a) external view and (b) architectural plan layout.

\subsection{Damage recognition after 1991 Banloc earthquake}

The Banloc earthquake, occurred on 1991 December $2^{\text {nd }}$, was a very significant event in the seismic historicity of the Banat region. It is characterized by a focal depth of $9 \mathrm{~km}$. The released seismic energy produced a magnitude $\left(\mathrm{M}_{\mathrm{w}}\right)$ of 5.5 on the Richter scale. This earthquake can be classified as a medium-deep geological event. It caused slight damages to new designed structures, but several masonry buildings in the area were characterized by very serious

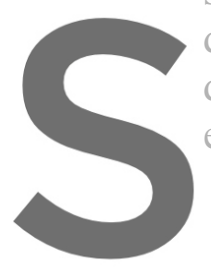
damages, also with partial collapses. Referrin detected through on-site inspections after the earthquake damages are presented in Eigure 3.
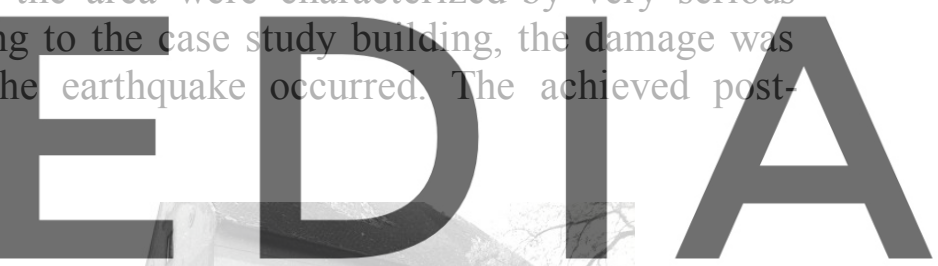

Register for free at https//www.scipedia.com to download the version without the watermark

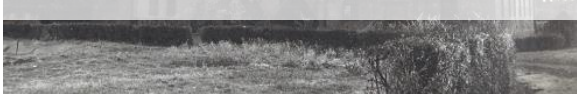

(a) - North façade

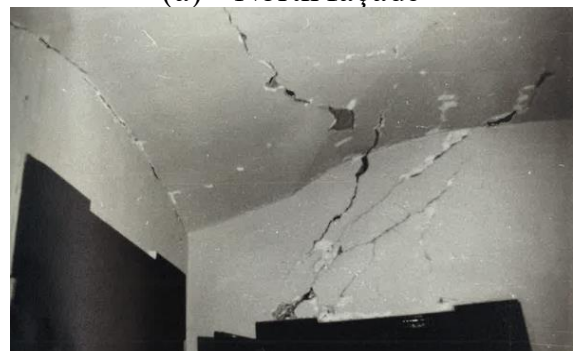

(c)

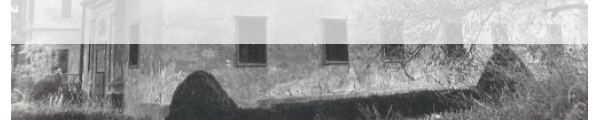

(b) - West façade

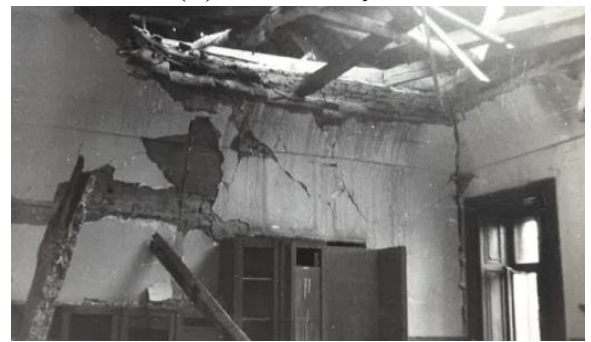

(d)

Figure 3: Damage reconnaissance on the study Castle after 1991 Banloc earthquake: (a, b) external façade; (c) first floor room; (d) second floor room [19]. 
As it is seen from the previous figures, the higher damage has been localized in the vaults, which are elements characterized by large spans and resistance lower than that of vertical structures (Figures $3 \mathrm{c}$ and $3 \mathrm{~d}$ ). In particular, the cracks in the vaults are attributable to the impulsive vertical component, which produced very extensive damages. Contrary, vertical structures were affected by shear (sliding or diagonal) mechanisms induced by horizontal seismic components with widespread cracks.

\section{NON-LINEAR DYNAMIC ANALYSIS}

\subsection{Ground motion characterization}

The accelerograms adopted are representative of the event occurred in Banloc in December 1991 considering the BNL1 seismometric station [9]. The accelerations are characterized by maximum components in $\mathrm{X}$ direction of $0,08 \mathrm{~g}$, in $\mathrm{Y}$ direction of $0,13 \mathrm{~g}$ and in $\mathrm{Z}$ direction of $0,13 \mathrm{~g}$ (Figures $4 \mathrm{a}$ and $4 \mathrm{c}$ ). The seismic phenomenon can be defined of near-source type, since the city of Banloc is located approximately at $7 \mathrm{~km}$ from the epicentre.

Furthermore, in order to contextualize the induced effects of the vertical component on the global vulnerability of the building, a 6 seconds time history has been considered. This choice is supported from the fact that, on one hand, in the first 6 seconds all the seismic energy input is concentrated, and, on the other hand, the analysis elaboration time is short [10].

In addition, the elastic spectra have been derived from the recorded accelerograms and have been processed with the-Seismosignalsoftware [11]. Consecutively, the spectral natios between vertical accelerations, $\mathbf{V}$, and the corresponding horizontal one ground motions recorde shown how the vertical component effects are more evident for small site-source distances shows that for short periods (around 0,2 secon
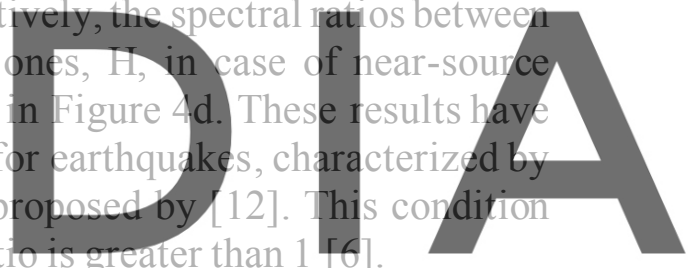

Register for freée at https//www scipediaj6om to downloagd the version without the watermark

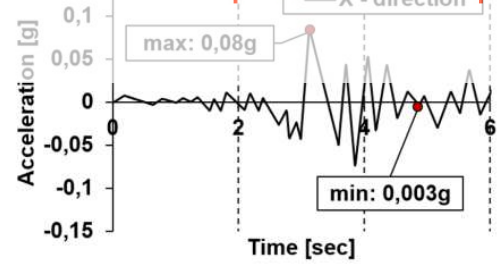

(a)

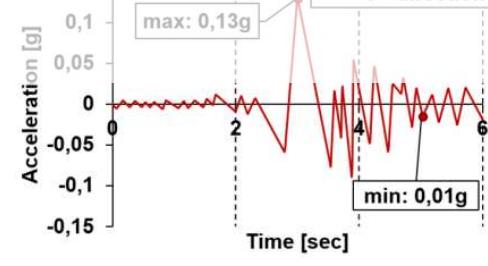

(b)

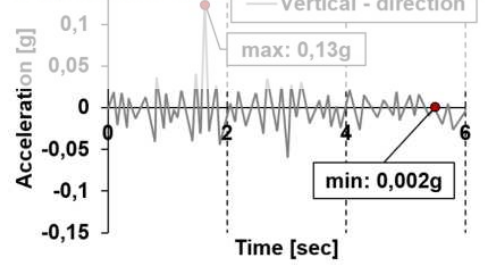

(c)

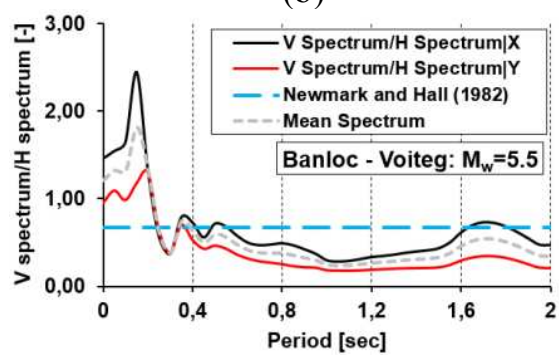

(d)

Figure 4: Accelerograms of the Banat-Voiteg seismic event in all directions (a-c) and V/H spectral ratios for near-source records. 


\subsection{Time-history analysis}

Time-history analysis provides a global assessment of the castle dynamic structural response varying specified ground motion accelerograms. The implementation of the model was set-up using the DIANA FEA software [13], where the structure has been modelled as set of interconnected shell elements (Figure 5).

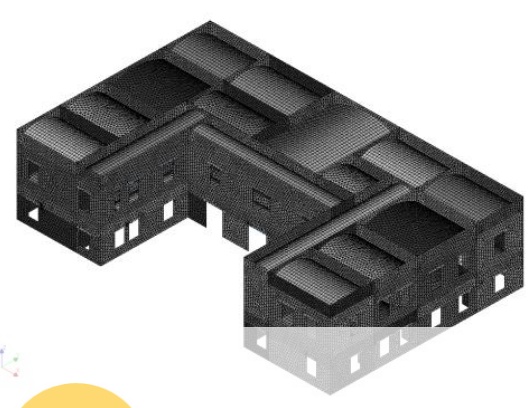

(a)

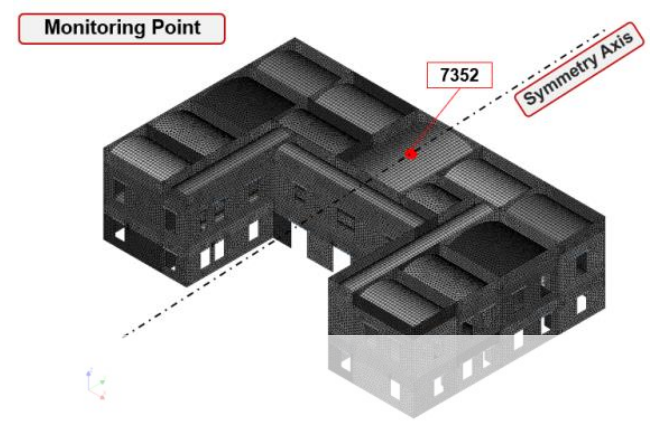

(b)

Figure 5: 3D-shell element model (a) and selected monitoring points (b).

Masonry has a non-linear response and manifests a nonductile post-peak softening behaviour; to this purpose, tensile stresses are assumed to diminish exponentially, while compression combines hardening and softening parabolic phases according to [14,15]. Based on this assumption, in study building have been shown.
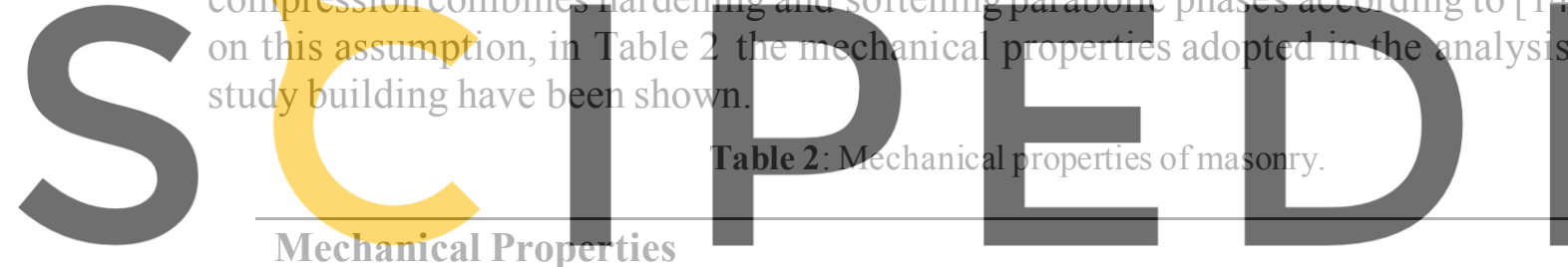

Modulus of elasticity

Register for free at https//www.scipedia.com to dotwhload

Compressive strength

Tensile strength

Specific weight

Poisson ratio

Fracture energy (compression)

Fracture energy - Mode I (tensile)

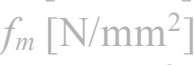

$\tau_{0}\left[\mathrm{~N} / \mathrm{mm}^{2}\right]$

$\mathrm{w}\left[\mathrm{KN} / \mathrm{m}^{3}\right]$

$v[-]$

$\mathrm{G}_{f c}[\mathrm{~N} / \mathrm{mm}]$

$\mathrm{G}_{f t}[\mathrm{~N} / \mathrm{mm}]$
1500 the version without the watermark

2.40

0.24

18

0.20

4.64

0.012

The results obtained have been represented, for the two scenarios considered, namely $(\mathrm{H})$ and $(\mathrm{H}+\mathrm{V})$, in terms of dispersion of both displacements and resistances. They are referred to the centroid of the second floor as monitoring point and are summarized in Figure 6. Concerning displacements and strengths regime, positive and negative values of the points cloud denote the change of direction induced by the seismic input with respect to the straight line with equation $\mathrm{x}=\mathrm{y}$ (bisector). Furthermore, in order to better highlight the influence of the vertical component, the upper $(y=0,5 \mathrm{x})$ and lower $(\mathrm{y}=2 \mathrm{x})$ bounds of the dispersion range have been considered. In this way, the greater scatter with respect to the bisector, the larger effect of the ground motion vertical component [6]. 


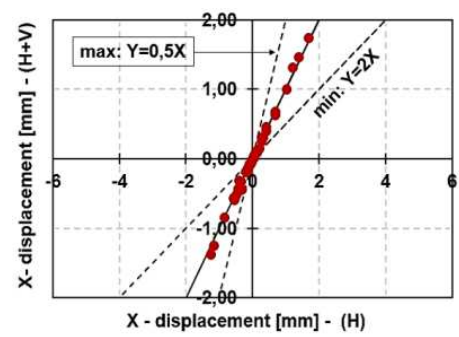

(a)

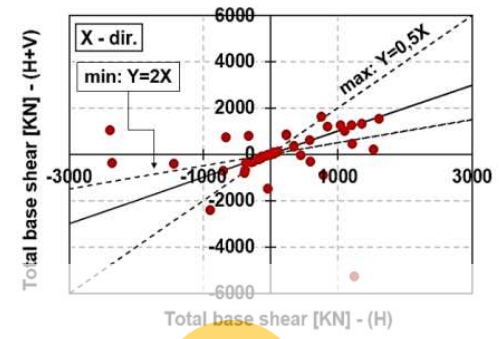

(d)

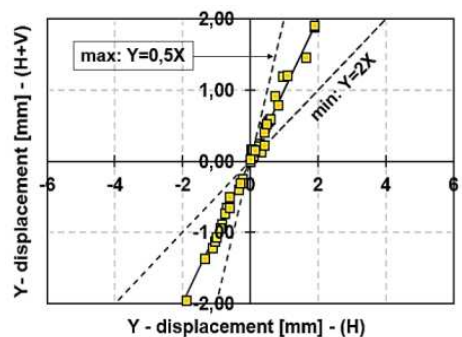

(b)

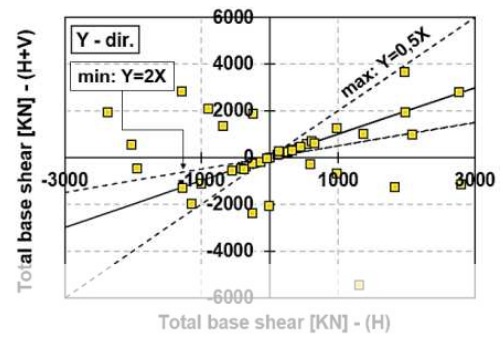

(e)

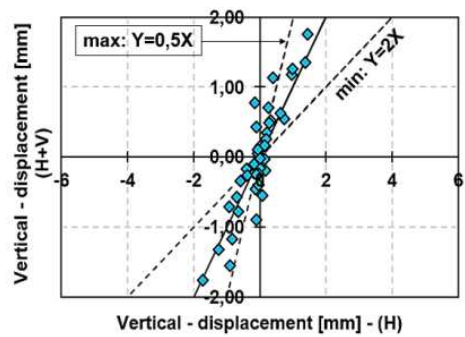

(c)

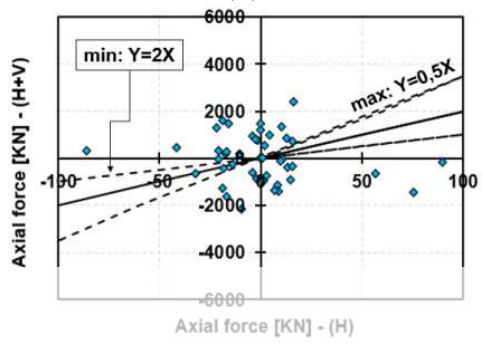

(f)

Figure 6: Scatter results in terms of displacements (a-c) and base shear (d-f).

From results obtained, it is possible to notice how the vertical component provides a variation of the displacements regime in vertical direction. Furthermore, regarding the strength regime, the effect of ground motion in vertical direction is more considerable and, therefore, the scatter associated is more marked. Consequently, in order to better contextualize the impulsive effect of the yertical seismic action, a time step of This choice has been done since in the first two second the yer releases all its energy input, is maximized. So, for the sake of and $(H+V)$ scenarios, the differences detected in terms $\phi$ f both shear [10] and axial demands for one of the most stressed pier of the West façade have been assessed. The achieved results,

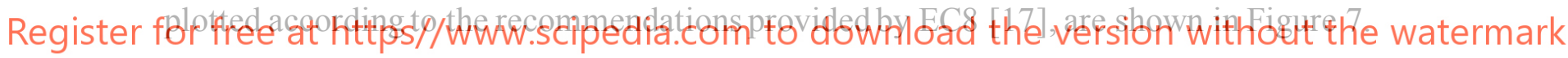

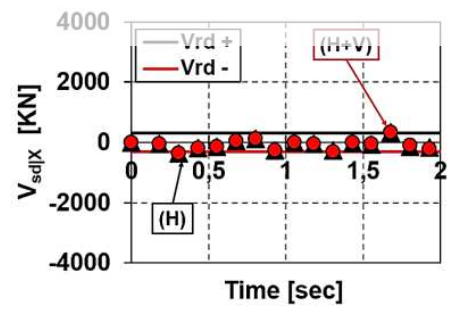

(a)

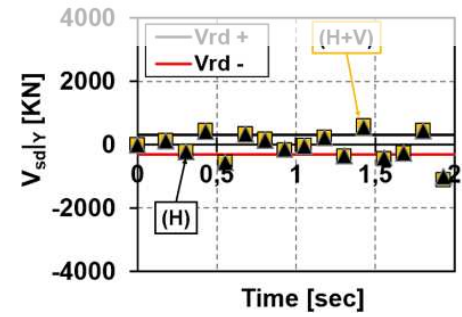

(b)

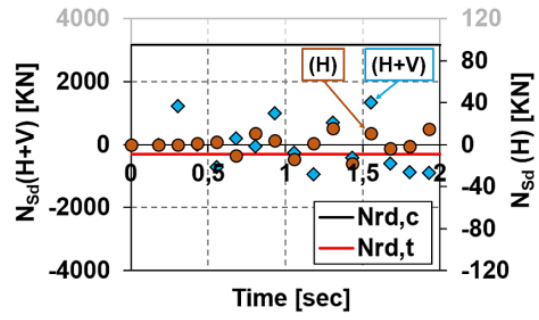

(c)

Figure 7: Safety checks for shear stresses (a-b) and axial loads $(c)$ in case of $(H)$ and $(H+V)$ scenarios.

Firstly, in Figures $7 \mathrm{a}$ and $7 \mathrm{~b}$, it is possible to notice how the seismic vertical component in the two main directions, $\mathrm{X}$ and $\mathrm{Y}$, does not produce any significant stress variation for both considered scenarios. Secondly, in Figure 7c, it is shown how the vertical component produces a significant increase in terms of axial load. In fact, at time step of 1.55 seconds (which corresponds to the maximum peak vertical acceleration), the difference between $(\mathrm{H})$ and $(\mathrm{H}+\mathrm{V})$ is very high (more than two times). Moreover, it is detected that the axial load demands exceed averagely the corresponding tensile capacities $\left(\mathrm{N}_{\mathrm{rd}, \mathrm{t}}\right)$ of 2 times. 


\subsection{Experimental-numerical damage comparison}

The reliability of the implemented numerical model is strictly based on the reproduction of the damages really achieved [18]. The damages detected by means of in-situ inspections after the Banloc earthquake are characterised by a widespread distribution of cracks, that affect the vertical and horizontal structures and produce globally the structure deterioration.

In particular, several failure mechanisms closely related to the seismic event were identified. More specifically, in the first two seconds of the time-history, the maximum vertical peak acceleration produced an extensive damage in the vaults, characterized by a brittle behaviour (Figure 8) [19].

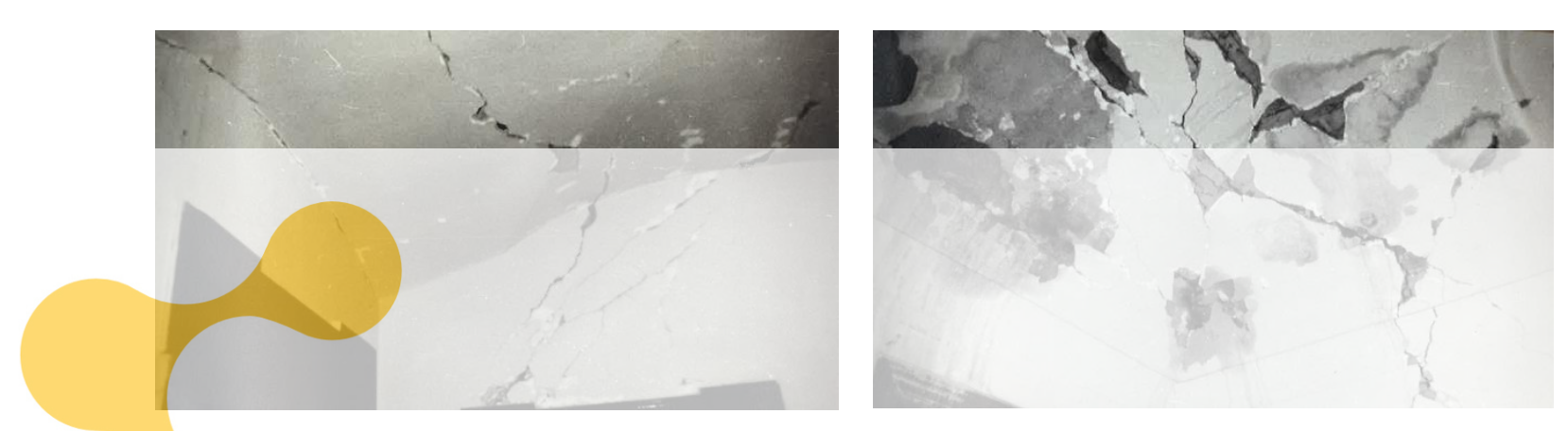

Figure 8: Damages detected in the second-floor vaults mainly due to ground motion vertical component [19].
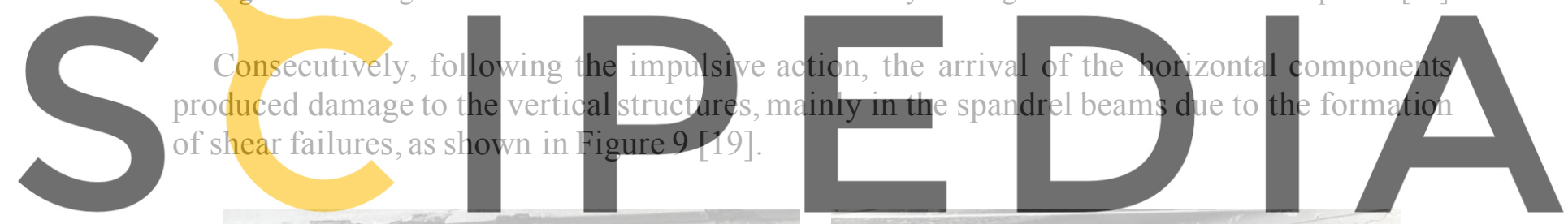

Register for free at https//www.scipedia.com to download the version without the watermark
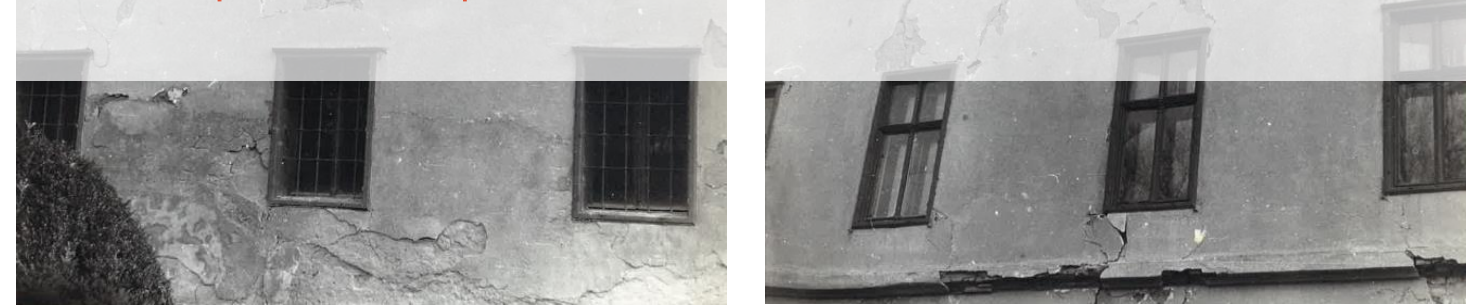

Figure 9: Vertical and diagonal shear cracks detected in the South façade of the case study building [19].

Finally, in the internal court of the building, a partial collapse of the roofing structure was observed. This collapse mechanism was triggered by the impulsive seismic action, as depicted in Figure 10 [19]. 


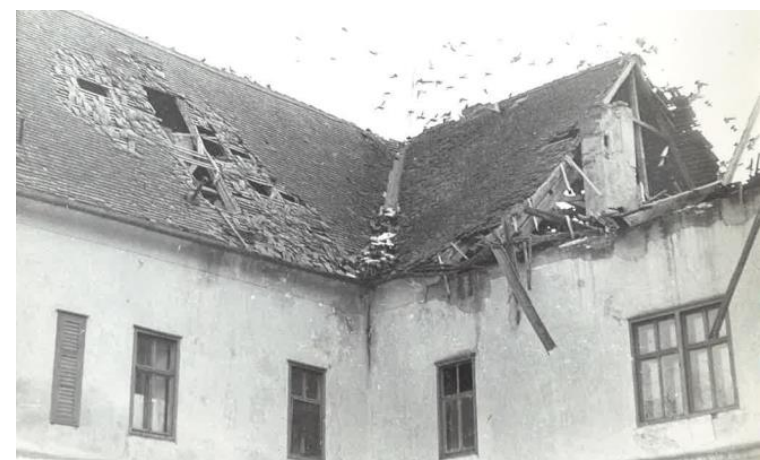

(a) - left view

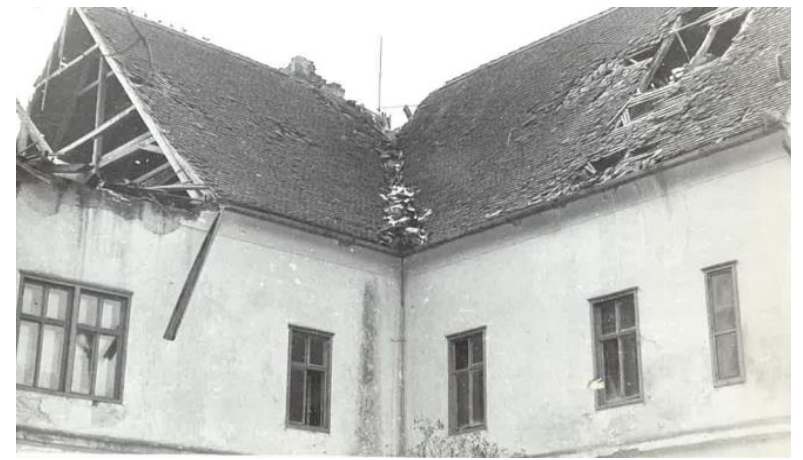

(b) - right view

Figure 10: Failure mechanisms observed in the internal court of the case study building [19].

The damages achieved from numerical analyses have been presented and compared to experimental ones in Figure 11.

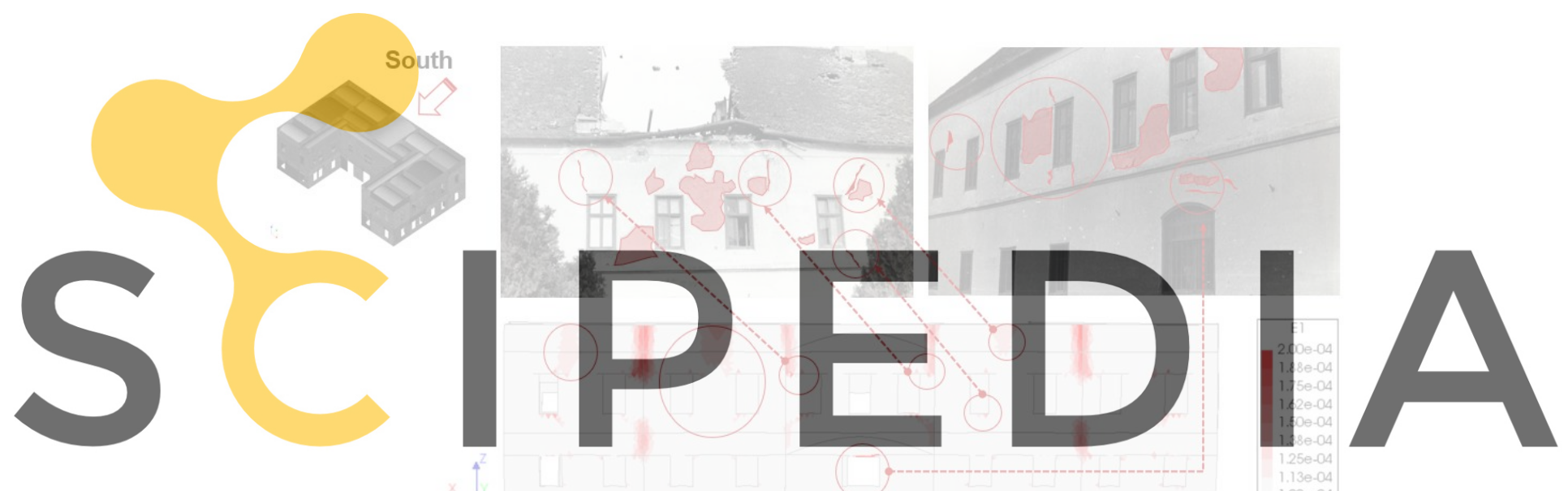

Register for free at https//www.scipedia.com to alownload the version without the watermark

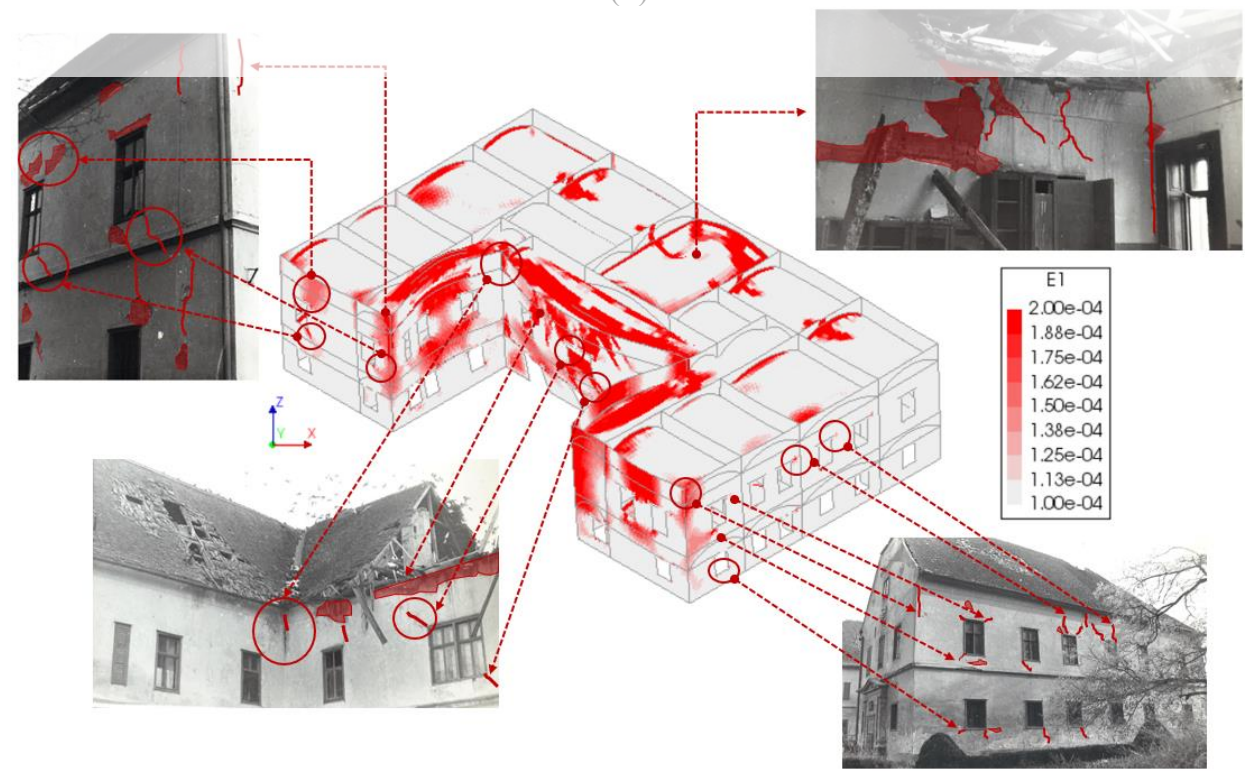

(b) 


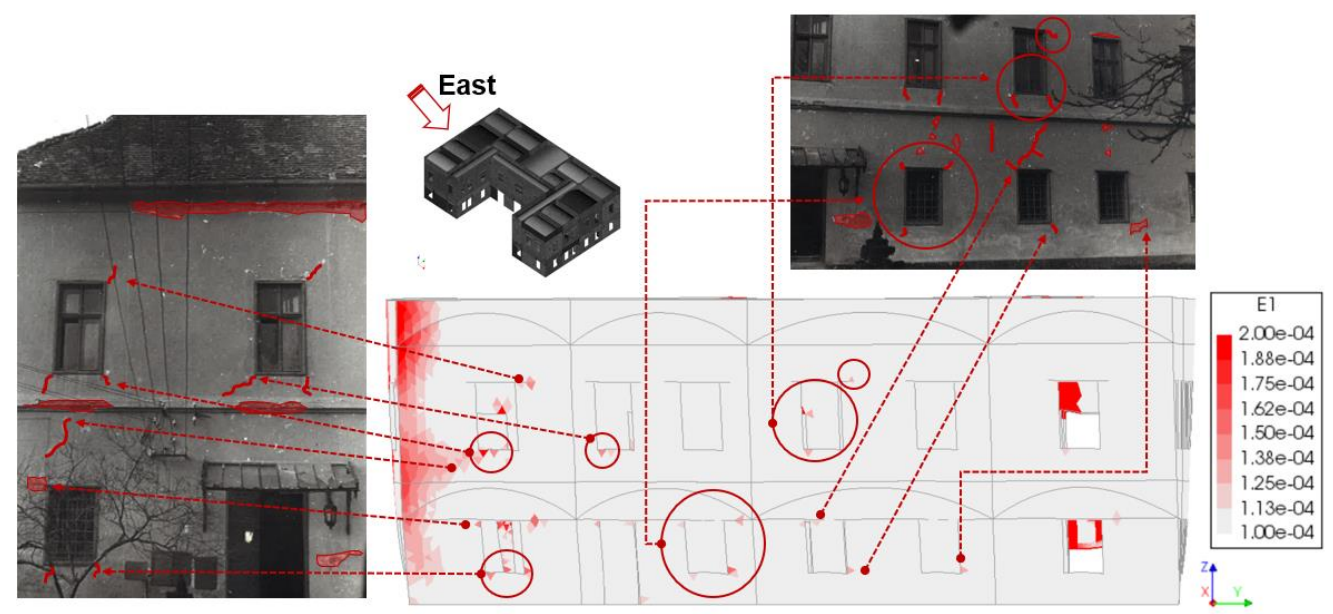

(c)

Figure 11: Numerical damages obtained simulating the Banloc-Voiteg event and comparison with experimental evidences.

From the above comparison, it appears that the non-linear analysis identified local damages very similar to those produced by the earthquake. The identification parameter used to evaluate the damage state in the numerical analysis is the tensile fracture energy $\left(G_{f}\right)$, according to which, when the maximum principal stress reaches the defined cracking criterion, the fracture

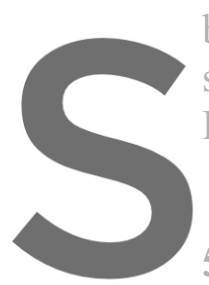
begins to distribute in the structural element. satisfactory way the detected 1 Figure 11, the right distributio

\section{CONCLUSIONS}
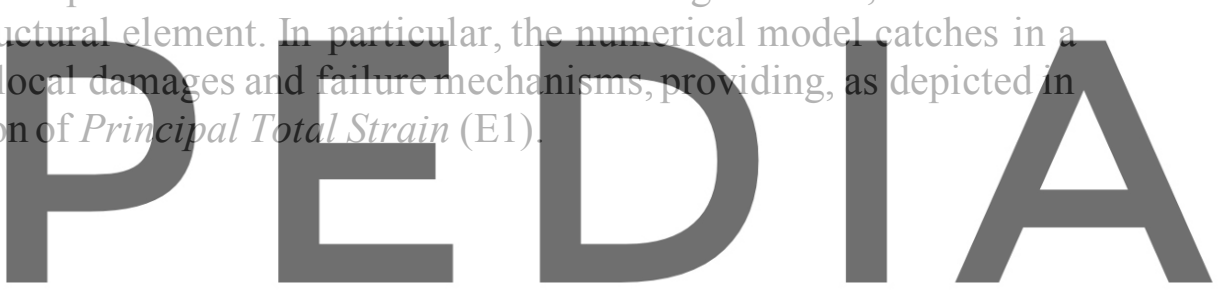

The proposed work has analysed the effects induced by the vertical earthquake component

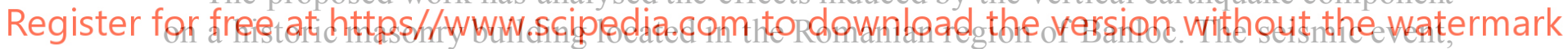

occurred in December 1991 with a moment magnitude of 5.5, was characterised by a small

(about of $7 \mathrm{~km}$ ) site-source distance. This impuisive event was identified by a seismic directivity, low frequency content and maximum PGAs comparable in vertical and horizontal directions. The accelerometric records were used to perform non-linear dynamic analyses on the case study building modelled with the DIANA FEA software using shell elements.

The effects of the ground motion vertical component were evaluated considering the comparison between two different scenarios: the first, named $\mathrm{H}$, where only horizontal acceleration components were considered, and the second, called $\mathrm{H}+\mathrm{V}$, where also the vertical components were taken into account. The main results are summarized as follows:

- The considered record, due to the combination of high magnitude and short site-tosource distance, had high energy in terms of vertical component.

- There was a dispersion of the displacements induced by the vertical component in the first two seconds of the time-history, since the impulsive action releases a high input energy in that time period.

- In the first two seconds of time history, where the maximum vertical energy content of the seismic motion occurred, the comparison of the two scenarios $(\mathrm{H}$ and $\mathrm{H}+\mathrm{V})$ in 
terms of stress regime was done. In particular, in terms of shear strength the vertical component does not produce any significant variation of results in the two-analysis directions. Conversely, referring to the axial stress regime, the vertical component induces a considerable increase of axial tensile loads, which exceeded averagely the corresponding tensile capacities of about 2 times.

- The numerical damage assessment was carried out considering the Principal Total Strains (E1), which take into account the overcoming of the tensile fracture energy in the structural elements. The numerical analysis results provided with satisfactory accuracy the same damage mechanisms really detected in the castle, namely cracks in the vaults (produced by vertical components) and vertical structures (mainly caused by horizontal components), as well as the out-of-plane horizontal bending mechanism in the façade facing the courtyard, which was produced by the partial collapse of the roofing structures.

Acknowledgements. The Authors would like to acknowledge Dr. Eng. Joao Pereira and Dr. Eng. Nuno Mendes from University of Minho for the interest demonstrated towards the present study and the suggestions provided on the use of the DIANA FEA software. Also, the contribution of Prof. Gian Piero Lignola from University of Naples Federico II, who provided very useful suggestions on the performed analyses, is gratefully acknowledged.

\section{REFERENCES}

[1] Mosoarca, M., Onescu I., Azap, B.; Onescu, E., Chieffo, N. Szitar-Sirbu, M. Seismic vulnerability assessment for the historical areas of the Timisoara city, Romania. Eng. Fail. Anal. (2019), 101:86-112.

[2] Chieffo, N., Clementi, F., Formisano, A., Lenci, S. Comparative fragility methods for seismic assessment of masonry buildings located in Muccia (Italy). Journal of Building Engineering, (2019), 25, 100813.

[3] Formisano, A. Theoretical and Numerical Seismic Analysis of Masonry Building Aggregates: Case Studies in San Pio Delle Camere (L'Aquila, Italy). Journal of Earthquake Engineering, (2017), 21:227-245.

[4] Onescu, I., Mosoarca, M., Azap, B., Onescu, E. Seismic Losses Scenario for Cultural Promenade in Timisoara Capital of Culture 2021, Romania. IOP Conf. Ser. Mater. Sci. Eng. (2019), 471, 102041.

[5] Chieffo, N., Formisano, A., Ferreira, T.M. Damage scenario-based approach and retrofitting strategies for seismic risk mitigation: an application to the historical Centre of Sant'Antimo (Italy). Eur. J. Environ. Civ. Eng. (2019).

[6] Di Michele, F., Cantagallo, C., Spacone, E. Effects of the vertical seismic component on seismic performance of an unreinforced masonry structures. Bull. Earthquake Eng. (2019), https://doi.org/10.1007/s10518-019-00765-3.

[7] Diotallevi, P.P., Landi, L. Effect of the axial force and of the vertical ground motion component on the seismic response of R/C frames. In: 12th World conference on earthquake engineering, (2000), Auckland. 
[8] Di Sarno, L., Elnashai, A.S., Manfredi, G. Assessment of RC columns subjected to horizontal and vertical ground motions recorded during the 2009 L'Aquila (Italy) earthquake. Eng. Struct. (2011), 33:1514-1535.

[9] Borcia, I.S., Craifaleanu, I.G., Calarasu, E.A. Examples of use of the SM-ROM-GL Database. In $5^{\text {th }}$ National Conference on Earthquake Engineering and $1^{\text {st }}$ National Conference on Earthquake Engineering and Seismology-5CNIS \& 1CNISS, Bucharest, Romania, (2014), 1:165-172.

[10] Panza, G., Romanelli, F., Vaccari, F. Realistic modelling of waveforms in laterally heterogeneous anelastic media by modal summation. Geophysical Journal International, (2000), 143:340-352.

[11] Seismosoft. SeismoSignal, User's Manual. 2018.

[12] Newmark, N.M., Hall, W.J. Earthquake spectra and design. EERI monograph series, (1982), Oakland.

[13] DIANA, Displacement methods ANAlyser, release 10.2, User's Manual. n.d.

[14] Lourenço, P.B., Pereira, J.M. Seismic Retrofitting Project, recommendations for advanced modeling of historic earthen site. The Getty Conservation Institute, LA (2018), ISBN: 978-1-937433-53-6.

[15] Mendes, N., Lourenço, P.B., Campos-Costa, A. Shaking table testing of an existing masonry building: Assessment and improvement of the seismic performance. Earthquake Engineering and Structural Dynamics, (2014), 43:247-266.

[16] Turnšek, V., Čačovič, F. Some experimental results on the strength of brick masonry walls. In Proceedings of the 2nd international brick masonry conference, (1971), 149-156.

[17] EN 1998-1:2004 (2004) Eurocode 8-Design of structures for earthquake resistance. Part 1: general rules, seismic actions and rules for buildings. European Committee for Standardization, Brussels.

[18] Mosoarca, M., Gioncu, V. Seismic management and damage prevention of religious buildings situated in seismic areas. Journal of Cultural Heritage, (2013) 14:e65-e72.

[19] IPROTIM TIMISOARA. Expertiza cu principii de consolidare (In Romanian). Pr. Nr. 35353/330, (1990). 